\title{
POINTS TO BE CONSIDERED IN THE ESTABLISHMENT OF LONG-TERM FIELD TRIALS
}

\author{
YRJÖ Pessi \\ Society of Peat Cultivation, Leteensuo, Finland
}

Received November 27, 1963

In the planning and arrangement of field tests the aim is to obtain reliable crop yield results and to carry out the calculations implied by statistical mathematics. Although certain errors due to experimental technique can be eliminated in some degree with the aid of statistical methods and e.g. the reliability of the test results can be examined, the maximum benefit is derived from the test only when the primary test results have the highest possible degree of reliability. In this respect the arrangement of one-year tests is frequently easier than that of tests lasting several years, since there is no necessity to take into account factors and changes which manifest themselves only in the course of prolonged periods. In the following this question will be considered on the basis of the experience gained in the field tests of several decades' duration at the Leteensuo Peat Experimental Station.

Soil homogeneity. The test arrangements aim at the highest possible degree of homogeneity of the soil in the test area. When necessary, this condition can be ascertained by means of an investigation. When the test has been planned for several decades, it is furthermore advisable to try to make sure that later no factors emerge which might produce inhomogeneity in the soil during the test period. One of these factors on cultivated peat land may prove to be the wear of the peat layer, as a result of which the influence of the deeper soil layers is increasingly emphasized in the course of the test. For instance, at Leteensuo one of the soil improvement tests had been established on an area with forest sedge peat along one margin at a thickness of $50 \mathrm{~cm}$ when the test was started and with Sphagnum peat under this layer. In the course of about 50 years' cultivation the peat layer has been worn down to the extent that the Sphagnum peat has become admixed with the tilled topsoil in the tilling operations and the soil of the test area has consequently become inhomogeneous to a degree that makes it advisable to discontinue the test. 


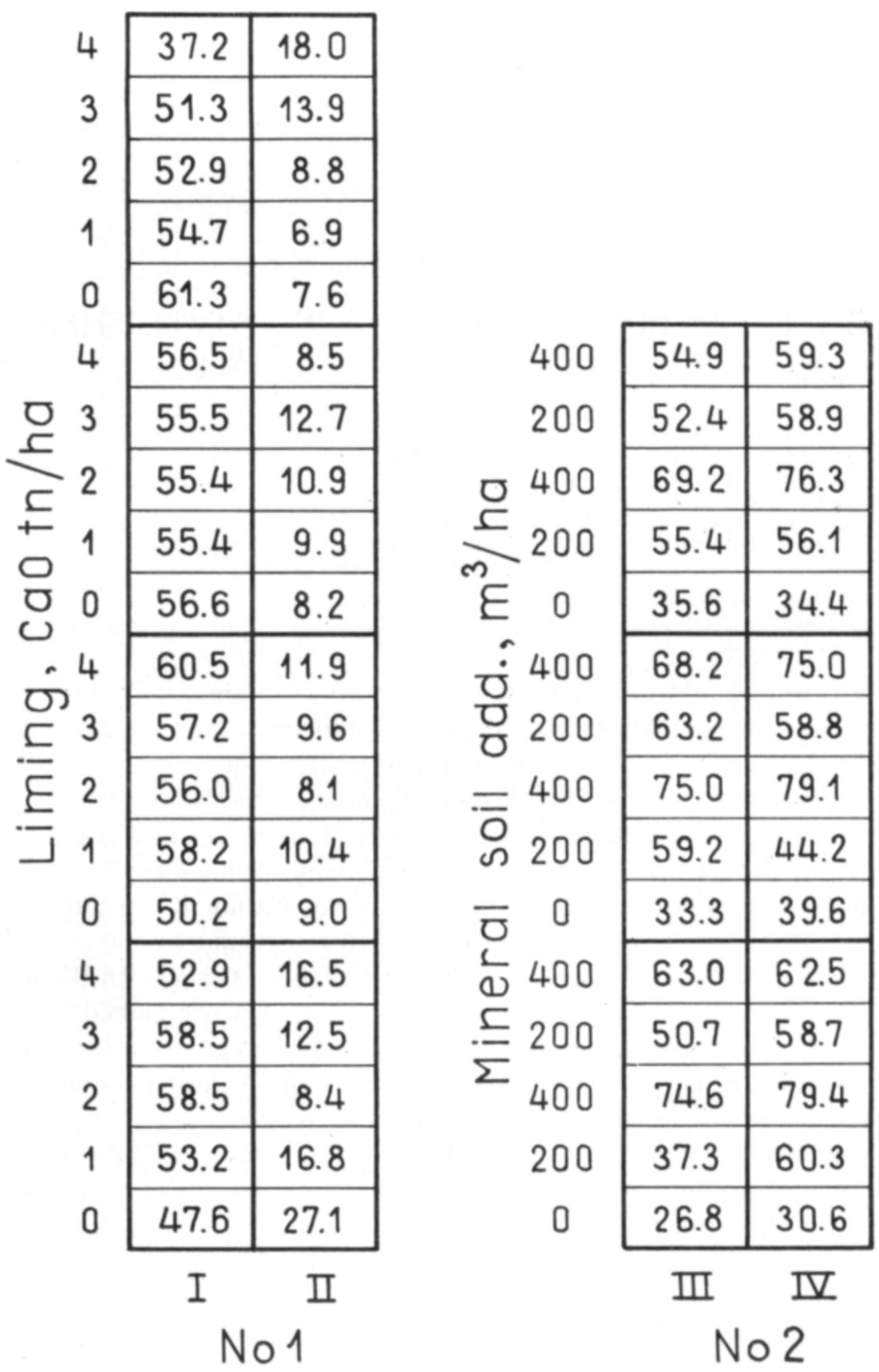

Fig. 1. The ash contents (per cent), of the tilled layers in soil improvement tests, after cultivation during 37 and 28 years (test No. 1 and No. 2, respectively). $I=$ Clayed, $I I=$ Without clay, $I I I=$ Without lime, IV $=$ Limed. 
On low-lying lands, in particular on cultivated peat land, inundations may occur which also produce inhomogeneity in the course of time, particularly when the water comes from mineral soils. We may cite as an example the ash content of the tilled layer found in a soil improvement test on fen land at Leteensuo. The test area is adjacent to a main ditch, which almost regularly inundates the area in the spring and sometimes also in the summer, the water coming from a silty clay area. The bog in question was cleared for cultivation in 1909 and the test started in 1910 (3). On the basis of the test, the significance of the varying sand and clay quantities as soil improvement agents on cultivated peat land is being studied, as well as aspects of fertilization of peat land. In 1960 the ash content in the tilled layer of three such strips which did not receive any mineral soil as soil improving agent was investigated. The strip $10 \mathrm{~m}$ away from the main ditch had the highest ash content, $29.1 \%$, that of the strip at a distance of $60 \mathrm{~m}$ was lower by 5.0 per cent units, while the lowest ash content, $20.7 \%$, was found in the strip lying $110 \mathrm{~m}$ from the ditch. This inhomogeneity in the ash content is highly detrimental in a test in which the effects of mineral substances as well as fertilizers are investigated.

Shape of the surface. The shape of the soil surface may be of significance in regard to the homogeneity in moisture conditions in the tilled layer. In the arrangement of long-term tests circumstances should also be taken into account which may in the course of time produce depressions in the test area from which the surface water cannot escape. The possibilites of levelling the test plots in such tests without disturbing the homogeneity of the tilled layer are usually very restricted. On cultivated peat lands depressions can come into being spontaneously in the course of time in case the settling of the peat layer is not quite uniform. In such an area the draining of the test field by open ditches may prove superior to drainage by buried drains. It is advisable, at all events, already when the test is established to try to shape the surface so that the best possible evacuation of the surface water from the test area is ensured even in case of a variable settling of the peat.

Variable settling of the soil in the course of time may also be due to the treatment of some given test member. This applies particularly to the soil improvement treatments on cultivated peat land. For instance, the author (2) has observed that on the Sphagnum peat land at Leteensuo the settling of the soil surface during 35 years was larger by $12.5 \mathrm{~cm}$ when claying had been done than on the unclayed test member. This variation in settling, which becomes evident in the course of time, should be taken into account in the shaping, location and draining of the test plots and, above all, in the shaping of the soil surface prior to the establishment of the test.

Location and shape of the test plots. In long-term tests, the potential disturbing effects of the tilling operations recurring each year should be taken into account already when the test is being planned. For instance, a location for the test where the tilling machines are not compelled to make their turns within the test area should be chosen. In fertilizing and soil improvement tests the transportation of soil from one plot to another by the tilling machines should be kept in mind. Two soil improvement tests on the Leteensuo Sphagnum bog area illustrate the effect of soil transport taking place during several decades on the characteristics of the tilled layer. 
I am referring to a claying und liming test (test No. 1) and a clay and sand addition test (test No. 2) (1). The first-mentioned was established in 1923 and the latter in 1932. In test No. 1, the claying was done by strips (10 m by $100 \mathrm{~m})$ and in test No. 2 by plots $(6.67 \mathrm{~m}$ by $15 \mathrm{~m})$. In 1960 the ash contents of the tilled layers in the tests were investigated, with results which are seen in Fig. 2. On the strength of the ash contents in the different test plots inferences can be drawn concerning the degree in which peat has been transported from one plot to another by the tilling machines. Test No. 1 had a location with catch ditches immediately at either end of the strips. It was consequently necessary to turn the machines around on the plots located at both ends. It can be noted that as a result soil has been carried over in considerable quantities from one test plot to another, as evidenced by the fact that in the headlands the ash content of the unclayed peat is considerably higher than closer to the centre of the strip, while correspondingly the clayed peat shows a lower ash content than closer to the centre.

The transportation of soil with the tilling machines from one plot to another is even more clearly evident in test No. 2, in which the ash content of the peat, prior to the establishment of the test, was the same as in test No. 1 (about $1 \%$ ). Since the soil improvement treatments in test No. 2 were applied by test plots, all plots which received no mineral soil addition are only $6.67 \mathrm{~m}$ in length in the direction in which the tilling machines moved. The ash content of the peat in these zero plots varies between 26.8 and $39.6 \%$, which indicates that considerable mixing of the soils of adjacent plots has taken place. A comparison of these figures with those noted in test No. 1, which has been in progress ten years longer, reveals the great significance of the shape of the test plots in a test of this kind. In test No. 1, in which the mineral soil was applied by strips, the ash content of the unclayed test member has remained considerably lower than in test No. 2. In the latter, the zero plot no longer satisfies the requirements that have to be placed on a zero test member.

\section{$S u m m a r y$}

On the basis of the experience gained in the long-term field tests at the Experimental Station of Leteensuo, some of the factors have been examined which have to be taken into consideration when tests of this kind are established. It is noted that in the course of time the soil may become increasingly inhomogeneous, e.g. owing to sludge brought in by inundations, and owing to the wear of the peat on cultivated peat land. An initial shaping of the soil surface is essential in the case of cultivated peat lands because non-uniform settling of the soil may occur in the course of time in the test area. The soil surface of the different test members may also settle in different degrees, depending on the treatment involved in the test. Because of soil transportation from one test plot to another, caused by the tilling operations, the location and shape of the test plots are of significance in long-term tests intended to clarify questions associated with soil characteristics. 


\title{
REFERENCES:
}

(1) PESSI, Y., 1959. Kivennäismaan vaikutuksesta rahkasuon maanparannusaineena Leteensuon koeaseman pitkäaikaisten kenttäkokeiden perusteella. Summary: On the effect of mineral soil improving agent on Sphagnum bogs on the basis of prolonged field tests at Leteensuo Experimental Station. Acta Agric. Fenn. 94: 241-268.

(2) - 1960. The effect of claying upon the settling of the soil surface on cultivated Sphagnum bogs. Selostus: Saveuksen vaikutus maan pinnan laskeutumiseen rahkasuoviljelyksellä. J. Sci. Agric. Soc. Finland 32: 5-7.

(3) - - 1961. Results from soil improvement and fertilizing test on fen land at Leteensuo. Ibid. 33: $223-232$.

\author{
SELOST US :
}

\section{PITKÄAIKAISTEN KENTTÄKOKEIDEN PERUSTAMISESSA HUOMIOONOTETTAVIA SEIKKOJA}

\author{
YRJö PEssı
}

\section{Suoviljelysyhdistys, Leteensuo}

Leteensuon koeaseman pitkäaikaisista kenttäkokeista saatuihin kokemuksiin nojaten on käsitelty eräitä tällaisten kokeiden perustamisessa huomioonotettavia seikkoja. On todettu, että aikaa myöten saattaa maaperä muuttua epähomogeeniseksi mm. tulvien kuljettaman lietteen vaikutuksesta sekä suoviljelysten turpeen kulumisen vuoksi. Alunperin tapahtuvalla maan pinnan muotoilulla on suoviljelyksillä tärkeä merkitys, sillä aikaa myöten saattaa tapahtua koealueella epätasaista painumista. Eri koejäsenten kohdalla voi suon pinta laskeutua myös eri tavoin koekäsittelystä riippuen. Koeruutujen sijoittelulla ja muodolla on merkitystä erityisesti sellaisissa pitkäaikaisissa kokeissa, joilla pyritään selvittämään maaperään liittyviä kysymyksiä. 